\title{
THE TIPULID GENERA BITTACOMORPHA AND PEDICIA.
}

\author{
BY J. M. ALDRICH, MOSCOW, IDAHO.
}

Bitracomorpha. Westwood, Lond. second species, sackenii, from a single Edinb. philos. mag., vi, 28 $\mathrm{r}\left(\mathrm{I} \mathrm{S}_{35}\right)$. damaged specimen, captured in The only known species up to I890 Nevada. This species and one was clavipes, described by Fabricius described in the present article both in his "Species insectorum" in $\mathrm{I} 78 \mathrm{I}$ occur in the neighborhood of Puget under the generic name of Tipula. In Sound. As von Röder's description his "Systema Antliatorum" (1805) he is not readily accessible to American referred it to the genus Ptychoptera, students, and does not include all the where it remained until Westwood important characters, I redescribe erected for it the present genus in 1835 .

In 1890 von Röder described the the species.

\section{Table of Species.}

I. All the tibiae ringed with snow white near the base; all the metatarsi white at base.

Tibiae not ringed, metatarsi white at tip, instead of base. sackenii $\mathrm{v}$. Röder.

2. Dorsum of thorax deep velvety black with a white middle line; second submarginal cell one-third as long as the first posterior. . . clavipes Fabr. Dorsum of thorax shining black, no. middle line of white; second submarginal cell half as long as first posterior.

Bittacomorpha sackenii Von Röder, Wiener entom. zeit. ix, 230.- $\delta$. Front infuscated, face yellow; both overlaid with a thin white sericeous coating; proboscis light yellow, palpi infuscated. Antennae 19-jointed, elongate, equalling the wing in length, uniform black in color. Thorax wholly pale yellow, except the dorsum which is shining black, the humeri, supraalar area, and a spot before the scutellum, yellow; between the coxae at the sides there is a black spot in each interval, considerably expanded in fully-colored specimens; metanotum and knob of halteres infuscated. Abdomen long, strongly clavate, black, with short, scattered white pile; the first segment pale at base, all the segments with a narrow pale distal band; second segment $\mathrm{I}^{3}$ times as long as the third, fourth and fifth each about equal to the third; claspers small, compact, black, with a pair of black palpi-like organs covered with black hairs. Femora pale at base, the apical half or more black, but in lighter specimens sometimes only an apical black ring; tibiae of the same color, not so light at base; metatarsi black, with white tip; second and third joints of tarsi white, the rest brown. Wings hyaline, along the apex distinctly hairy, venation as in $B$. clavipes.

Length, II $\mathrm{mm}$; of wing, $7 \frac{1}{2} \mathrm{~mm}$.

$\%$. Antennae shorter, wings longer and wider, the latter scarcely exceeding half the length of the former. 
Five males, two females, Seattle, Washington, at Lake Union, the last of August and first few days of September, 1894 .

Bittacomorpha occidentalis, n. sp. $q$. Head wholly black, the front and the pointed face with a white sericeous covering; the antennae would extend about to the tip of the first abdominal segment, if bent back along the sides. Thorax black, the dorsum wholly shining; scutellum yellow; pleura white sericeous, a spot before the root of the wing and one above the base of the halters yellowish-pollinose. Abdomen black, the posterior margins of the segments narrowly whitish. Femora pale at base gradually darker to the tip, which is black; tibiae ringed with white near the base; second and third tarsal joints, and the base of the metatarsi, white; the metatarsus is as long as the following joints taken together, and its black part is somewhat swollen. Wings hyaline, the second submarginal cell almost half as long as the first posterior.

8. The antennae are broken off from my only specimen; abdomen less clavate than in $B$. sackenii, the appendages dark brown with pale hairs.

Length, 18-19 mm.; of wing $\delta, 8 \frac{1}{2}$, o , I I $\frac{1}{2} \mathrm{~mm}$.

One male, two females, Seattle, Wish. One specimen was collected the last of August, I 894, at Lake Union.

This is possibly the species referred to in Osten Sacken's note to $B$. clavipes, Catalogue, p. 36, where he says, "Specimens from California in Mr. Verrall's collection in London have a shining thorax and a shorter submarginal cell ; they may belong to a different species." They could not belong to occidentalis unless the word "shorter" in the quotation were a slip of the pen for "longer."
Bittacomorpha clavipes Fabr.

One female Custer, S. D. (Black Hills, 5000 feet), August, I892, in a moist meadow.

Comparing Osten Sacken's notes in "Weistern Diptera," p. 207, and in his catalogue, p. 36, it may reasonably be doubted whether the true clavipes has yet been found west of the Rocky. Mountains.

Pedicia. Latreille, Gen. Crust. Ins. iv, 255, 1809 .

This genus is a somewhat difficult one to determine, from the fact that the palpi have the same structure as in the section longipalpi, while the venation and other characters make it out a member of the brevipalpi. In other words, it is a brevipalp Tipulid with long palpi. Several years ago I received from $\mathrm{Mr}$. Chas. Palm a fine

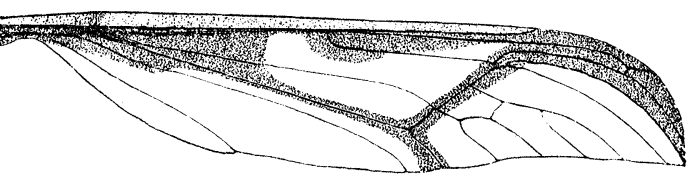

Pedicia albivitta Walk. $\sigma^{\pi} \cdot \frac{3}{1}$

male of $P$. albivitta Walk., the only eastern species, a particularly handsome insect, which remained an enigma to me for a long time. In Baron Osten Sacken's monograph no figure of the wing is given, and as the venation is very peculiar, I annex a figure to facilitate the recognition of the genus. The genus Amalopis Haliday is somewhat similar in venation, but has the brown coloring, if at all, in an entirely different pattern. 
Pedicia obtusa Osten Sacken, Western Dipt., 205. - The description of this species given by Osten Sacken was only a provisional one, covering the salient features, owing to the fact that he did not have the specimen before him at the time, but depended upon Mr. Hy Edwards, the owner of the type, to write him the characters. As I have a specimen, I record the full description.

d. Head small, grayish, the antennae yellow, palpi brown; frontal tubercle distinct, close to the antennae. Thorax grayish sericeous, ground color yellow, a double brown line on the dorsum and an abbreviated one each side of it, reaching to the transverse suture; on the pronotum a narrow median black line; a black stripe from the humerus to the base of the wing. Disk of metathorax and knobs of halters infuscated. Abdomen light brown, darker along the median line; the horny genital appendages are rather elongate, yellow, not infuscated. Legs brownish yellow, tips of femora and tibiae more infuscated, tarsi dark brown. Wings hyaline and brown, with almost the same pattern as in $P$. albivitta. The tip of the wing is not bent back so far as in the latter species. The brown color follows the fifth vein to the margin, differing in this respect from $\mathrm{Mr}$. Edwards's specimen.

Length, $28 \mathrm{~mm}$.; of wing, $22 \mathrm{~mm}$.

Lake Union, Seattle, Washington, the last of August.

The most important structural difference between this and $P$. albivitta is in the male lamellae, which are more than twice as large in the present species.

\title{
GALL OF EURYTOMA SP. ON THE CAT'S.CLAW THORN.
}

\author{
BY C. H. TYLER TOWNSEND, LAS CRUCES, N. MEX.
}

Specimens of a very hard rounded gall were found on branches and twigs of the cat's-claw thorn (Acacia sp.), which grows plentifully from near base to part way up the Organ Mts., at the north end of the range, about three miles southeast of San Augustine. These galls greatly resemble those of Rhodites. At the date on which they were found, Nov. 26, 1892, they appeared to be empty, the insects having mostly escaped through numbers of small holes in each gall. The galls were quite plentiful. From those containing exit holes, the following brief description is drawn.

Gall. - Length (measured on twig), ro to $19 \mathrm{~mm}$.; greatest width $8 \frac{1}{2}$ to $16 \mathrm{~mm}$.
Oblong-rounded or suboval, very hard, always formed on one side of the twig, the other side of the twig even with the surface of the gall and its bark left intact, the bark of the rest of the twig or branch being split by the growing of the gall and adhering to its surface in imperfect strips, being best preserved next the sides of twig. Smaller specimens do not show this. Color reddish brown, more or less grayish where covered with bark and in smaller galls. Bulged surface that is not covered by bark finely roughened, sometimes more or less split in process of swelling.

Four galls. The small ones show only from one to three holes each. A larger gall shows about twenty exit holes, and in addition numbers of very minute holes through which parasites of the gall flies must have escaped. The minute holes are about 

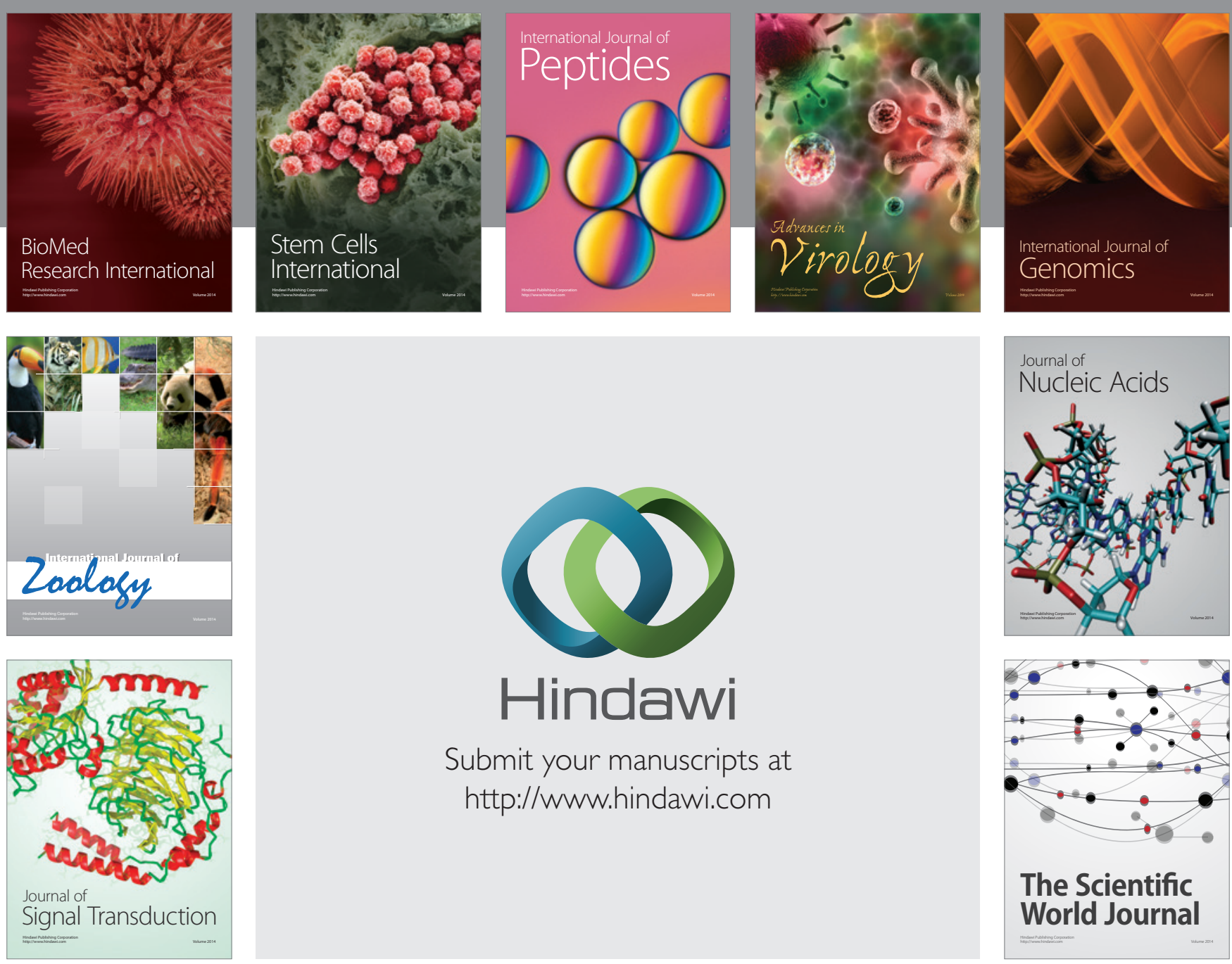

Submit your manuscripts at

http://www.hindawi.com
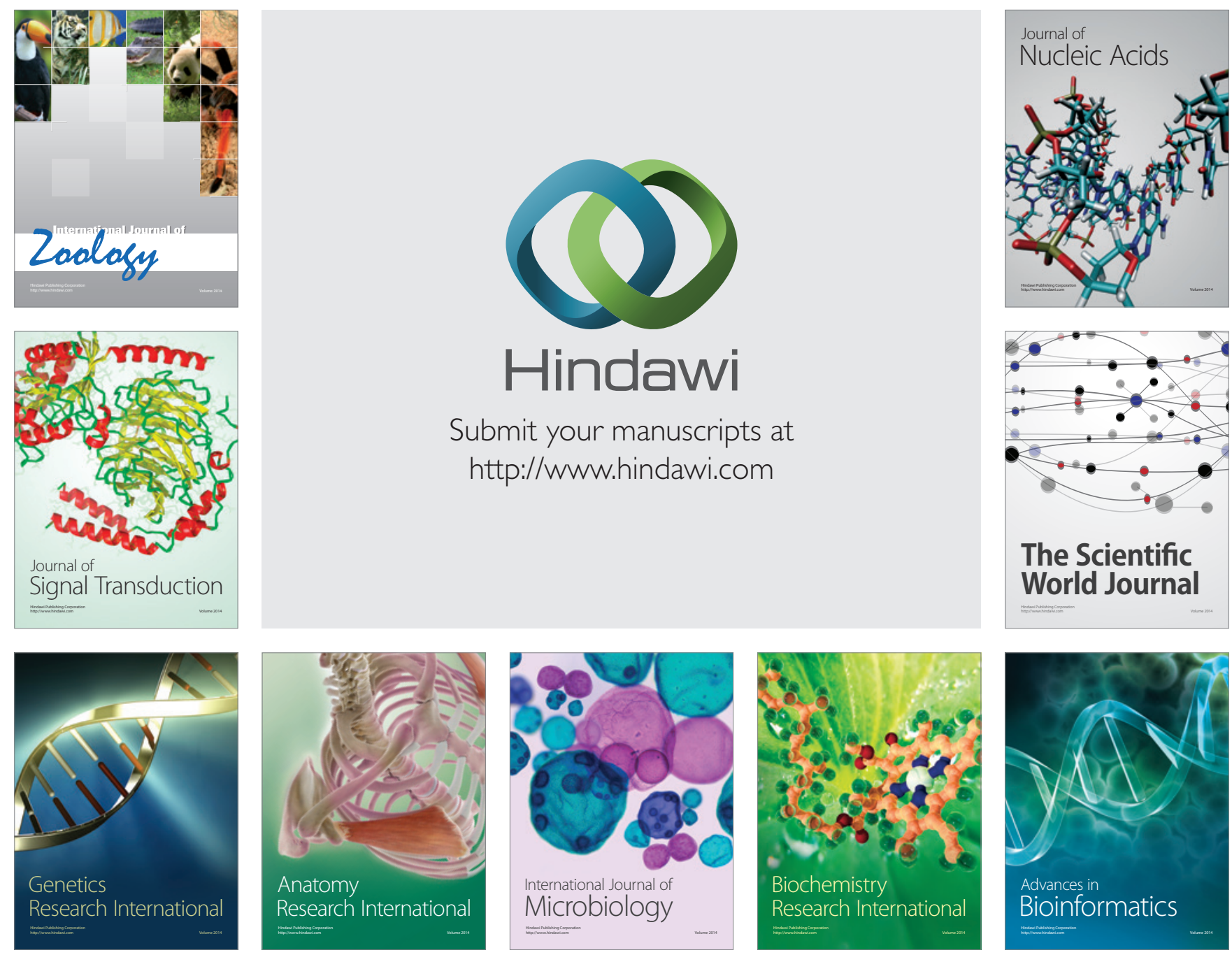

The Scientific World Journal
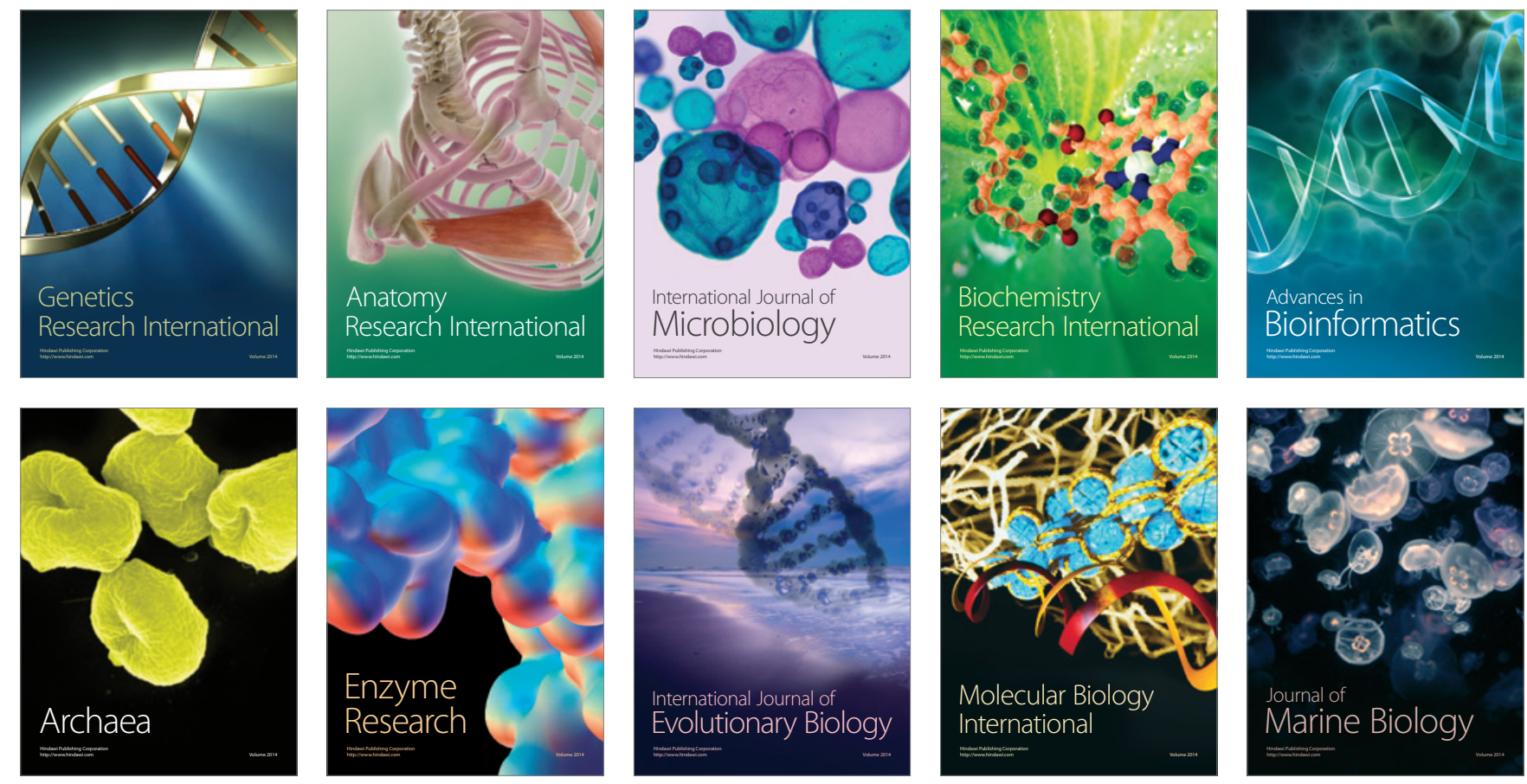